\title{
Comparative retinal histomorphometry and visual acuity of three bat species of the genus Artibeus (Phyllostomidae: Stenodermatinae) ${ }^{1}$
}

\author{
Erivaldo A. Antonio ${ }^{2,4 *}$ (D), Fabrício B. de Sá2 ${ }^{2}$ Katharine R.P. Santos ${ }^{3}$, Nivaldo B. Lima \\ Junior $^{2}$, Fabricya R. Silva², Francisco C.A. Aguiar Júnior ${ }^{3}$ and Jeymesson R.C. Vieira ${ }^{4}$
}

\begin{abstract}
Antonio E.A., de Sá F.B., Santos K.R.P., Lima Junior N.B., Silva F.R., Aguiar Júnior F.C.A. \& Vieira J. R. C. 2020. Comparative retinal histomorphometry and visual acuity of three bat species of the genus Artibeus (Phyllostomidae: Stenodermatinae). Pesquisa Veterinária Brasileira 40(11):933-945. Departamento de Morfologia e Fisiologia Animal, Universidade Federal Rural de Pernambuco, Rua Dom Manoel de Medeiros s/n, Dois Irmãos, Recife, PE 52171-900, Brazil.E-mail: eribaldi17@hotmail.com

This study performed a histomorphometric analysis of the retina and estimated the visual acuity of three fruit-eating bats of the genus Artibeus, including Artibeus lituratus, Artibeus planirostris and Artibeus obscurus. In total, 13 animals were used for this study, in which the retinas were hemidisected, fixed, cut, and stained. The visual acuity was determined by the density of ganglion cells in the retina and the retinal layers were also measured from histological sections. The retinas of these bats are avascular, do not present tapetum lucidum in any quadrant, and have the 10 retinal layers common in mammals. Moreover, it was observed that the thickness of the retina in the central region was significantly higher in all measured parameters ( $\mathrm{p}<0.001)$, except for the outer plexiform layer (OPL) which was significantly higher in the peripheral region $(p<0.001)$. The retinas of the three species showed a horizontal visual streak with a higher concentration of retinal ganglion cells (RGCs) at the inferotemporal region. In addition, the species A. lituratus exhibited extras areas of high cell density in the retina. Thus, A. lituratus showed the highest visual acuity (1.92 cycles/ degree), while A. planirostris showed a visual acuity of (1.77 cycles/degree) and $A$. obscurus exhibited the lowest visual acuity ( 1.50 cycles/degree). All these characteristics are related to the echolocation system and the eating habits of each species. Therefore, it can be concluded that bats of the genus Artibeus have a high visual acuity value compared to other echolocating bats and all these differences might be directly linked to the phylogeny of the genus.
\end{abstract}

INDEX TERMS: Fruit-eating bats, Artibeus, retinal histomorphometry, visual acuity, morpholgy.

\section{RESUMO.- [Histomorfometria comparada da retina e acuidade visual de três espécies de morcegos do gênero Artibeus (Phyllostomidae: Stenodermatinae).]}

\footnotetext{
${ }^{1}$ Received on July 14,2020

Accepted for publication on August 19, 2020.

${ }^{2}$ Departamento de Morfologia e Fisiologia Animal, Universidade Federal Rural de Pernambuco (UFRPE), Rua Dom Manoel de Medeiros s/n, Dois Irmãos, Recife, PE 52171-900, Brazil. *Corresponding author: eribaldi17@hotmail.com

${ }^{3}$ Núcleo de Biologia, Centro Acadêmico de Vitória (CAV), Universidade Federal de Pernambuco (UFPE), Rua Alto do Reservatório s/n, Bela Vista, Vitória de Santo Antão, PE 55608-680, Brazil.

${ }^{4}$ Departamento de Histologia e Embriologia, Centro de Biociências, Universidade Federal de Pernambuco (UFPE), Av. Prof. Moraes Rego s/n, Cidade Universitária, Recife, PE 50760-420, Brazil.
}

Este estudo realizou uma análise histomorfométrica da retina e determinou os valores de acuidade visual de três espécies de morcegos do gênero Artibeus, incluindo Artibeus lituratus, Artibeus planirostris e Artibeus obscurus. Em total, 13 animais foram usados para esse estudo, no qual as retinas foram hemidissecadas, fixadas, cortadas e coradas. A acuidade visual foi determinada pela densidade de células ganglionares na retina e também foi realizado a mensuração das camadas retinianas a partir de cortes histológicos. As retinas dessas três espécies são avasculares, não apresentaram tapetum lucidum em nenhum quadrante e possuem as 10 camadas retinianas comum em mamíferos. Verificou-se também que a espessura da retina na região central foi significativamente maior em todos os parâmetros mensurados $(\mathrm{p}<0,001)$, com exceção da camada plexiforme externa (OPL) que foi 
significativamente maior na região periférica $(p<0,001)$. As retinas das três espécies exibiram uma especialização retiniana em forma de faixa visual horizontal apresentando a maior concentração de células ganglionares na região inferotemporal. Além disso, a espécie A. lituratus exibiu áreas extras de alta densidade celular na retina. Assim, a espécie $A$. lituratus exibiu a maior acuidade visual (1,92 ciclos/grau), A. planirostris mostrou um valor intermediário entre essas duas espécies (1,77 ciclos/grau) e A. obscurus exibiu a menor acuidade visual (1,50 ciclos/grau). Todas estas características estão relacionadas aos padrões de ecolocalização e hábitos alimentares de cada espécie. Portanto, pode-se concluir que os morcegos do gênero Artibeus têm um alto valor de acuidade visual em comparação com outros morcegos ecolocalizadores e todas essas diferenças devem estar diretamente ligadas à filogenia do gênero.

TERMOS DE INDEXAÇÃO: Morcegos frugívoros, Artibeus, histomorfometria retiniana, acuidade visual, morfologia.

\section{INTRODUCTION}

The Order Chiroptera is the second largest group of mammals in number of species. These animals exhibit a unique morphology adapted to flight and a diverse food habits (Reis et al. 2007, Gardner 2008). Bats of the genus Artibeus Leach, 1821 (Phyllostomidae, Stenodermatinae) are restricted to the Neotropical region and it currently consists of 10 species distributed from Mexico to the north of Argentina and southern Brazil (Koopman 1982, Owen 1987, Marques-Aguiar 1994, Lim et al. 2004, Simmons 2005, Gardner 2008, Redondo et al. 2008, Solari et al. 2009, Reis et al. 2011, Ferreira et al. 2014). Besides, bats of this genus are mainly frugivorous and they play an important role in forest regeneration acting as seed dispersers, especially in early successional forests (Mikich 2002, Passos \& Passamani 2003, Galetti \& Morellato 2004, Passos \& Graciolli 2004, Oprea et al. 2007, Oliveira \& Lemes 2010, Martins et al. 2014, Bôlla et al. 2018, Pereira et al. 2019).

Recently, bats have been classified according to new molecular data and following the evolutionary process of the echolocation system (Teeling et al. 2000, Jones \& Teeling 2006, Teeling 2009). Although most bats use echolocation for orientation and to forage in the dark, they also use the vision to perform these tasks (Rydell \& Eklöf 2003, Altringham 2011, Gutierrez et al. 2018a, Warnecke et al. 2018). The vision is important for echolocating bats to find shelters (Ruczynski et al.2011), migration and homing (Griffin 1970, Williams \& Williams 1970), prey capture (Rydell \& Eklöf 2003) avoidance-escape behavior of obstacles and predators (Gould 1977, Chase 1981, Koay et al. 2002, Eklöf \& Jones 2003, Orbach \& Fenton 2010) and visual recognition (Suthers et al. 1969, Gutierrez et al. 2014, Rodríguez-Herrera et al. 2019). Furthermore, frugivorous and nectarivorous bats can see the brightness and the spectral composition of different food resources (Neuweiler 2000, Winter et al. 2003, Müller et al. 2009). So far, researchers have found evidences that there is a relationship between nocturnal activity peaks and feeding strategies with the visual skills of echolocating bats (Chase 1981, Rydell \& Eklöf 2003, Eklöf et al. 2014, Gutierrez et al. 2014, 2018a, 2018b, Kries et al. 2018).

The eyeballs of bats are constituted by three concentrically arranged tunics, one big lens, and a chambers system
(Neuweiler 2000, Cunningham 2004). The retina covers internally the entire posterior region of the eyeball (Pedler \& Tilley 1969, Leite et al. 2013). In echolocating bats, this nervous tunic is quite thin and it is formed by different types of neurons organized in 10 layers (Neuweiler 2000). Most bats have a dichromatic color vision due to the presence of two cone opsins, (S-) cone opsins and (L-) cone opsins related to sensitivity to short wavelengths and middle-long wavelengths, respectively. Furthermore, some species are able to see into the ultraviolet spectrum (Wang et al. 2004, Müller et al. 2007, Feller et al. 2009, Müller et al. 2009, Zhao et al. 2009, Boonman et al. 2013, Kries et al. 2018, Sadier et al. 2018, Simões et al. 2018, Gutierrez et al. 2018b). The eyes of these animals are adapted to operate in low light levels, resulting in poor visual acuity when compared to diurnal mammals (Suthers \& Wallis 1970, Pettigrew et al. 1988, Heffner et al. 2001). In general, frugivorous bats have bigger eyes and better visual resolving power compared to other bat species (Blackwood et al. 2010). Moreover, it has been shown that bat eyes work better in dim light than in bright light, especially fruit-eating bats that are more efficient at detecting and capturing their food during luminosity similar to a full moon (Hope \& Bhatnagar 1979, Gutierrez et al. 2014, Spoelstra et al. 2017, Gutierrez et al. 2018a).

The measurements of visual acuity are used to estimate the ability of an animal to perceive visual details. Thus, the visual acuity can be estimated anatomically by measuring the focal distance of the eyes and the peak density of retinal ganglion cells (RGCs) (Pedler \& Tilley 1969, Collin \& Pettigrew 1988, Pettigrew et al. 1988, Heffner et al. 2001, Müller et al. 2007, Ullmann et al. 2011, Hauzman et al. 2014, Veilleux \& Kirk 2014). The high-density of RGCs might appear of two ways: Located in a central area or horizontally, forming a visual streak, usually found in species that needs a horizontal viewing in open fields which the distribution of cells may vary according to the habit of each species (Hughes 1977, Collin 2008).

Information about the vision or morphophysiology of the ocular bulb of bats is scarce, especially of those species found in Brazil. Therefore, this study aimed to carry out a histomorphometric analysis to evaluate the topographic distribution of neurons in the central and peripheral region of the retina of three fruit-eating bats of the genus Artibeus (Artibeus planirostris, Artibeus lituratus and Artibeus obscurus) from a fragment of the Atlantic Forest of Pernambuco, Brazil. Additionally, it was estimated their respective visual acuity and the relationship between the visual capability and the feeding habits of this genus.

\section{MATERIALS AND METHODS}

Bat captures. In total, 05 adult males of the species Artibeus planirostris, 05 adult males of the species Artibeus lituratus and, three adult males of the species Artibeus obscurus were used in this study. The bats were collected by 10 mist nets ( $12 \mathrm{~m}$ long x $3 \mathrm{~m}$ high) at an Atlantic Forest fragment located in Tamandaré, Pernambuco, Brazil (Latitude: $08^{\circ} 44^{\prime} 13^{\prime \prime}$ and $08^{\circ} 43^{\prime} 09$ S and Longitude: $35^{\circ} 10^{\prime} 11^{\prime \prime}$ and $35^{\circ} 11^{\prime} 02^{\prime \prime} \mathrm{W}$ ). All procedures were carried out according to the international practices for animal use and care approved by the Ethics Committee on Animal Use of the "Universidade Federal de Pernambuco" (CEUA-UFPE), under protocol number 23076.040931/2014-76. 
Eye enucleation. After each capture, the animals were anesthetized at the capture site with sodium pentobarbital at a concentration of 40mgkg-1 intraperitoneally, followed by euthanasia with a saturated solution of potassium chloride (Morais et al. 2013). Before enucleation, radial incisions were made on the dorsal pole of the cornea using a portable cautery. Briefly, both eyes were extracted from the orbit through lateral incisions in the periorbital fat and extrinsic muscles using a scalpel and microsurgical scissors, preserving a portion of the optic nerve as much as possible (Moshfeghi et al. 2000, Ullmann et al. 2011). Subsequently, the eye axial length (AL) was measured through digital calipers to an accuracy of $0.01 \mathrm{~mm}$. Finally, all right eyes were hemisected, the cornea and iris were cut and the lens and vitreous were removed, as well as a radial cut was made on the dorsal region of the eyecup for future orientation (Ullmann et al. 2011).

Tissue processing and preparation of retinal wholemounts. After enucleation, the tissue processing and the retinal wholemounts were prepared following the methods of Stone (1981) and Ullmann et al. (2011). The right eyecups were fixed in $4 \%$ paraformaldehyde in $0.1 \mathrm{M}$ sodium phosphate buffer ( $\mathrm{pH} 7.2-7.4$ ) for 24 hours. After fixation, the eyecups were washed in PBS and the retinas were dissected by removing sclera and the choroid using surgical tweezers and a paintbrush. The bleaching process was not necessary because all retinas were easily detached from the retinal pigment epithelium. Subsequently, the dissected retinas were wholemounted on gelatinized slides with the optic fiber layer uppermost and other radial cuts were made to enable the retina to lie completely flat and adhere on the slide. The retinas were exposed to formalin vapor at $60^{\circ} \mathrm{C}$ for 2 hours and dried in the vessel for another 24 hours. Retinal wholemounts were immersed in $4 \%$ paraformaldehyde for 1 hour and then rehydrated in decreasing sequences of ethanol. After washing in distilled water, the tissues were Nissl stained with an aqueous solution of $0.05 \%$ cresyl violet for 10 minutes, dehydrated in an ethanol series, cleared in xylene, and coverslipped with Entellan (Stone 1981, Ullmann et al. 2011). The percentage of retinal tissue shrinkage may vary according to each species. Therefore, retinal pictures were taken and the retinal surface area was measured using the Image Software version 1.44 (Research Services Branch, U.S. National Institutes of Health, Bethesda/MD, USA) before and after staining so that shrinkage could be estimated (Stone 1981, Lisney et al. 2012).

The left eyes were fixed following the same process of the right eyes. However, they were used to examine the microanatomy of the eye and the layered structure of the retina. Thus, the left eyes were processed according to routine histological techniques. They were embedded in paraffin and sectioned into $4 \mu \mathrm{m}$ thickness in serial sections, beginning from the temporal to nasal area in each eye. Then, the tissue preparations were stained with hematoxylin and eosin (HE) and analyzed by light microscopy (Tolosa et al. 2003).

Retinal ganglion cells topography and histomorphometric analysis of the retina. To count and mapping the topography of the retinal ganglion cells (RGCs), as well as to measure the retinal layers, several photomicrographs at 400x magnifications were taken at each quadrant in the central and peripheral retina of the three species. The photomicrographs were obtained by the computer program ScopePhoto using a digital capture camera (Moticam 2300), of 3.0 megapixels, coupled to an optical microscope (Nikon E-200). A systematic random sampling scheme was used to map the density distribution of the RGCs on each wholemount (Ullmann et al. 2011, Coimbra et al. 2012, Lisney et al. 2012). First of all, it was established that the central retina was a circular area with a radius of about $2,000 \mu \mathrm{m}$ from the optic nerve head, whereas the peripheral retina were those regions greater than $2,000 \mu \mathrm{m}$ from the optic nerve head (Schlamp et al. 2013). Counts of RGCs were performed using a counting frame of $100 \times 100 \mu \mathrm{m}$ from the temporal region to the nasal region measured using the plugin Grid of the ImageJ software version 1.44. Counts were made at $100 \mu \mathrm{m}$ intervals in the periphery and $50 \mu \mathrm{m}$ intervals in the center of the retina. All RGCs within the counting frame and all RGCs intersected by the upper and right border of the counting frame were included, while all those intersected by the lower and left border of the counting frame were disregarded (Gundersen 1977). Moreover, only RGCs were considered for counting, and amacrine and glial cells were excluded. To distinguish the RGCs from other neurons was used the cytological criteria, which RGCs were those cells that always exhibited a large and irregular shape, a well-stained nucleus with a prominent nucleolus and Nissl granules in the cytoplasm (Hughes 1981, Collin 1988, Collin \& Pettigrew 1988, Coimbra et al. 2012). Finally, to calculate the visual acuity and to map the topographic pattern distribution of RGCs the cell counts were converted to cells $/ \mathrm{mm}^{2}$. To create the topography maps, ganglion cell isodensity contour plots were created and smoothed by joining retinal regions of equal density (Ullmann et al. 2011, Moore et al. 2012, Garza-Gisholt et al. 2015). Topographic maps were created using Freehand (Adobe Systems Incorporated, San Jose/CA, USA). Subsequently, the average of RGCs density of each retinal contour plots was multiplied by its area and then the results of all contour plots were added up in order to estimate the total RGCs present in the retina of each species (Harahush et al. 2014).

Histomorphometric measurements were made using photomicrographs of cross-section of the retina at 400x magnifications. The photomicrographs were obtained using the same images capture devices for counting of RGCs. The total retinal thickness (excluding the retinal pigment epithelium) and seven retinal layers were measured in micrometer $(\mu \mathrm{m})$ using the software ImageJ. The retinal layers measured were: photoreceptors outer and inner segment (PS), outer nuclear layer (ONL), outer plexiform layer (OPL), inner nuclear layer (INL), inner plexiform layer (IPL), ganglion cell layer (GCL) and nerve fiber layer (NFL). Thus, 10 photomicrographs were considered for each quadrant in the central and peripheral regions of the retinas and the results were compared between regions and among the three species. Additionally, it was established the average number of layers of photoreceptors nuclei from the outer nuclear layer $(\mathrm{ONL})$ in the central region of the retina.

Estimation of visual acuity. The visual acuity or anatomical spatial resolving power was calculated following the equations of Williams \& Coletta (1987) and Pettigrew et al. (1988). First of all, the posterior nodal distance (PND) should be determined for each eye of the animals and it was calculated using a method established by Pettigrew et al. (1988). They proposed that to estimate the PND the axial length of the eyeballs should be multiplied by ( 0.52 ). This 0.52 value is a constant related to the mean ratio of PND regarding the axial length for nocturnal species, including microchiropteran bats. Second, to estimate the visual acuity from the retinal ganglion cells density, the retinal magnification factor (RMF) must be calculated. The RMF is the linear distance on the retina that subtends $1^{\circ}$ of visual angle. Therefore, the RMF was estimated in micrometers per degree $(\mu \mathrm{m} /$ degree $)$ and it was calculated according to the following formula (Pettigrew et al. 1988):

$$
\mathrm{RMF}=\frac{2 \pi * \mathrm{PND}}{360}
$$

Finally, the RMF was used to figure out the visual acuity for the three species of Artibeus. Thus, the visual acuity was calculated using 
the Nyquist limits of spatial resolution according to the following equation (Williams \& Coletta 1987):

$$
\mathrm{Fn}=\frac{\mathrm{RMF}}{2} \sqrt{\frac{2 \mathrm{D}}{\sqrt{3}}}
$$

Where, Fn is the highest spatial frequency that can be detected under optimal light conditions by the eyes, and D represents the highest RGCs density located in the retina (cells $/ \mathrm{mm}^{2}$ ). Therefore, the visual acuity is the maximum number of retinal ganglion cells per linear degree and it was estimated in cycles per degree (cycles/degree).

Statistical analysis. The mean values obtained from each parameter analyzed for the three species were compared by Student's t-test and analysis of variance (ANOVA) using the software SPSS (Statistical Package for the Social Sciences, SPSS Inc. Chicago, EUA) version 15.0. The results were expressed as mean \pm SD (standard deviation), with a significance level of $5 \%(P<0.05)$.

\section{RESULTS}

\section{Axial length and retinal area}

Anatomical measurement of the eyeball of these three bats showed that Artibeus lituratus have the biggest and Artibeus obscurus have the smallest eyes among these three species. The values of the eye axial length (averaged between the right and left eyes for each species) are shown in Table 1 . The retina of the three bat species covers internally the posterior region of the eyes until the ora serrata. Thus, the area of the retina of the species A. lituratus is significantly larger $(p<0.001)$ among these bats with approximately $\left(18.96 \mathrm{~mm}^{2} \pm 0.12\right)$, while the retinal area of Artibeus planirostris is $\left(14.23 \mathrm{~mm}^{2} \pm 0.10\right)$ and the retina of $A$. obscurus covers about $\left(11.39 \mathrm{~mm}^{2} \pm 0.27\right)$ the inner region of the eye.

\section{Retinal ganglion cells distribution}

The ganglion cell density was significantly higher $(p<0.001)$ in the center of the retina compared to the peripheral region. Besides, the highest concentration of RGCs was observed at the inferotemporal region of the retina, especially below the optic nerve head, ranging from 10,700 to $11,300 \mathrm{cell} / \mathrm{mm}^{2}$ for the three bat species (Fig.1). No tissue correction was applied to cell density due to the shrinkage was minimal, located only in narrow zones in the borders of the retina and in the edges of some radial cuts. No apparent foveal pit or depressed part of the retina was identified. However, the highest concentration of RGCs is relatively a large circular area without any depression that was characterized as an areae centrales. Furthermore, a weakly pronounced horizontal visual streak was verified extended along the temporonasal axis in all three retinas. Thus, the peak density of RGCs is located within the visual streak close to the optic nerve head (Fig.2). The species A. lituratus exhibits another slightly horizontal visual streak beginning from the temporal quadrant until the nasal quadrant located just above the optic nerve head. Moreover, it shows a considerable circular area with a high density of RGCs at the superonasal quadrant (Fig.1A). Similarly, the retina of the species A. planirostris exhibits a great concentration of RGCs above the optic nerve head continuous within the horizontal visual streak (Fig.1B). The total number of RGCs for each species was estimated and the results are expressed in Table 1.

\section{Visual acuity}

Assuming the highest density of RGCs at a specific site in the retina, the species $A$. lituratus showed the highest visual acuity (1.92 cycles/degree) when compared with the other two. On the other hand, $A$. obscurus had the lowest visual acuity (1.50 cycles/degree), and the species $A$. planirostris exhibited an intermediate value of visual acuity (1.77 cycles/ degree) (Table 1).

Table 1. Data base for visual acuity of Artibeus lituratus, Artibeus planirostris and Artibeus obscurus

\begin{tabular}{|c|c|c|c|c|c|c|c|}
\hline Species & $\mathrm{AL}(\mathrm{mm})$ & $\begin{array}{l}\text { Estimated } \\
\text { PND (mm) }\end{array}$ & $\begin{array}{c}\text { RMF } \\
(\mu \mathrm{m} / \text { degree })\end{array}$ & $\begin{array}{l}\text { Retinal area } \\
\left(\mathrm{mm}^{2}\right)\end{array}$ & $\begin{array}{l}\text { Estimated total } \\
\text { number of RGCs }\end{array}$ & $\begin{array}{c}\text { Highest density of } \\
\text { RGCs } / \mathrm{mm}^{2}\end{array}$ & $\begin{array}{c}\text { Estimated visual acuity } \\
\text { (cycles/degree) }\end{array}$ \\
\hline \multicolumn{8}{|c|}{ Artibeus lituratus } \\
\hline No. 1 & 3.71 & 1.92 & 33.49 & 19.00 & 108,220 & 11,391 & 1.92 \\
\hline No. 2 & 3.74 & 1.94 & 33.84 & 18.99 & 107,005 & 11,322 & 1.93 \\
\hline No. 3 & 3.76 & 1.95 & 34.01 & 19.07 & 112,059 & 11,650 & 1.97 \\
\hline No. 4 & 3.68 & 1.91 & 33.31 & 18.75 & 100,371 & 10,950 & 1.87 \\
\hline No. 5 & 3.71 & 1.92 & 33.49 & 18.99 & 103,420 & 11,187 & 1.90 \\
\hline Mean \pm SD & $3.72 \pm 0.03$ & 1.93 & 33.66 & $18.96 \pm 0.12$ & $106,215 \pm 4,493$ & $11,300 \pm 258$ & $1.92 \pm 0.04$ \\
\hline \multicolumn{8}{|c|}{ Artibeus planirostris } \\
\hline No. 1 & 3.52 & 1.83 & 31.92 & 14.24 & 80,938 & 10,776 & 1.78 \\
\hline No. 2 & 3.54 & 1.84 & 32.09 & 14.25 & 87,158 & 10,889 & 1.79 \\
\hline No. 3 & 3.51 & 1.82 & 31.74 & 14.20 & 82,447 & 10,935 & 1.77 \\
\hline No. 4 & 3.56 & 1.85 & 32.27 & 14.37 & 85,015 & 10,850 & 1.79 \\
\hline No. 5 & 3.51 & 1.82 & 31.74 & 14.09 & 78,442 & 10,550 & 1.75 \\
\hline Mean \pm SD & $3.52 \pm 0.02$ & 1.83 & 31.92 & $14.23 \pm 0.10$ & $82,800 \pm 3,408$ & $10,800 \pm 151$ & $1.77 \pm 0.02$ \\
\hline \multicolumn{8}{|c|}{ Artibeus obscurus } \\
\hline No. 1 & 2.97 & 1.54 & 26.86 & 11.12 & 64,575 & 10,450 & 1.48 \\
\hline No. 2 & 3.03 & 1.57 & 27.38 & 11.66 & 66,950 & 10,700 & 1.52 \\
\hline No. 3 & 2.91 & 1.51 & 26.34 & 11.39 & 63,550 & 10,950 & 1.48 \\
\hline Mean \pm SD & $2.97 \pm 0.06$ & 1.54 & 26.86 & $11.39 \pm 0.27$ & $65,025 \pm 1,744$ & $10,700 \pm 250$ & $1.50 \pm 0.02$ \\
\hline
\end{tabular}




\section{Retinal morphometry}

The retinas of these three species are avascular and did not present tapetum lucidum in any retinal quadrant. Furthermore, for all three species of Artibeus it is formed by 10 layers (Fig.3). It was observed that the thickness of the central region of all retinas is significantly higher $(p<0.001)$ in all measured parameters for the three species, except for the outer plexiform layer (OPL) which is significantly higher in the peripheral region of the retina $(p<0.001)$. However, the retinal thickness varies significantly in a great number of parameters when compared between the species (Table 2).

The species A. lituratus exhibited the highest total retinal thickness in the central region compared to the other two, whereas $A$. obscurus showed the highest total thickness in the peripheral region of the retina. The layer thickness of the outer and inner segments of photoreceptors (PS) was

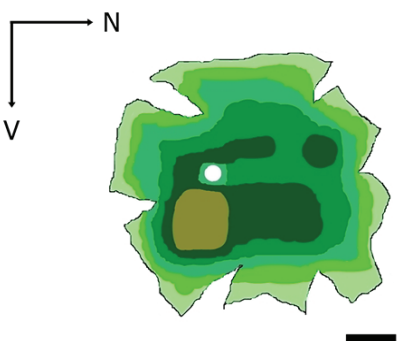

A

D

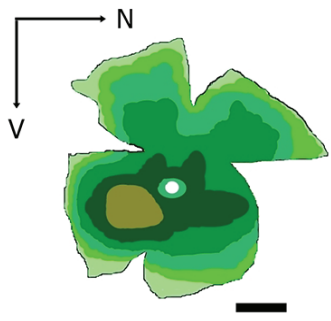

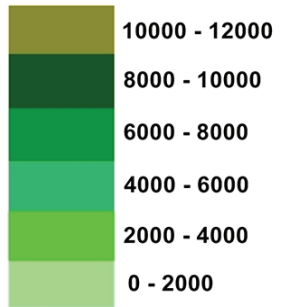

$\mathrm{RGCs} / \mathrm{mm}^{2}$

Fig.1. Isodensity topographic map representing the distribution of retinal ganglion cells (RGCs) in the retinas of (A) Artibeus lituratus, (B) Artibeus planirostris and (C) Artibeus obscurus. All three species show a horizontal visual streak and the highest concentration of RGCs located at the inferotemporal region of the retina (brown area) with a maximum density of approximately $11300 \mathrm{RGCs} / \mathrm{mm}^{2}, 10800$ $\mathrm{RGCs} / \mathrm{mm}^{2}$ and $10700 \mathrm{RGCs} / \mathrm{mm}^{2}$ to Artibeus lituratus, Artibeus planirostris and Artibeus obscurus, respectively. Ventral (V), nasal (N), optic nerve head (white dot). Bar $=1 \mathrm{~mm}$.
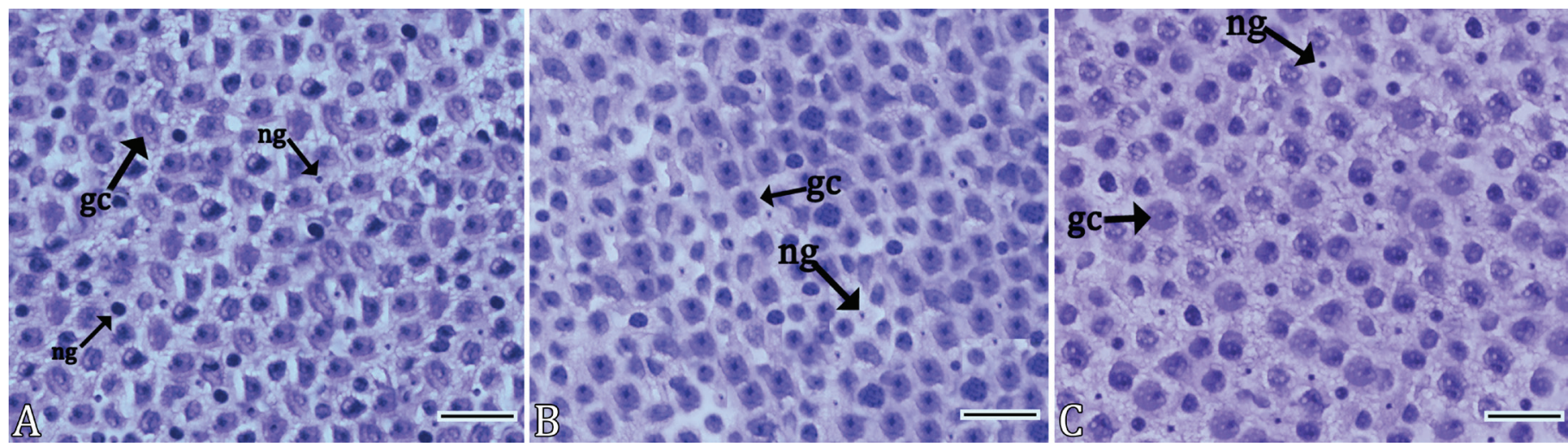

Fig.2. High-magnification digital photomicrographs of the Nissl-stained retinal ganglion cell layer of (A) Artibeus lituratus, (B) Artibeus planirostris and (C) Artibeus obscurus showing ganglion cells bodies (gc) and examples of nonganglion cells (ng), which were not included in the neuron counts. All three photomicrographs were taken from the inferotemporal region of the retinas (the highest concentration of RGCs). Nissl stain, obj.40x, bar $=20 \mu \mathrm{m}$.

Table 2. Thickness of the central and peripheral layers of the retinas of Artibeus lituratus, Artibeus planirostris and Artibeus obscurus

\begin{tabular}{|c|c|c|c|c|c|c|}
\hline \multirow{2}{*}{ Parameters } & \multicolumn{2}{|c|}{ Artibeus lituratus } & \multicolumn{2}{|c|}{ Artibeus planirostris } & \multicolumn{2}{|c|}{ Artibeus obscurus } \\
\hline & Center & Periphery & Center & Periphery & Center & Periphery \\
\hline Total retinal thickness* & $147.01 \pm 1.46$ & $131.13 \pm 0.81$ & $128.29 \pm 0.66$ & $124.79 \pm 0.79$ & $137.79 \pm 2.15$ & $132.18 \pm 1.98$ \\
\hline PS & $36.07 \pm 1.04$ & $23.98 \pm 1.31(\mathrm{a})(\mathrm{b})$ & $27.14 \pm 0.73$ & $23.69 \pm 0.72(a)(c)$ & $26.51 \pm 1.57$ & $23.60 \pm 1.05(b)(c)$ \\
\hline ONL & $46.66 \pm 0.75$ & $40.32 \pm 0.95$ & $42.87 \pm 2.14$ & $36.09 \pm 1.04$ & $38.23 \pm 2.2$ & $33.62 \pm 1.54$ \\
\hline OPL & $7.31 \pm 0.41$ & $8.39 \pm 0.77$ & $9.50 \pm 0.17$ & $15.95 \pm 0.41$ & $10.32 \pm 1.08$ & $13.59 \pm 1.1$ \\
\hline INL & $20.95 \pm 0.47$ & $16.60 \pm 0.93$ & $22.81 \pm 0.59$ & $15.96 \pm 0.41$ & $22.25 \pm 1.80$ & $18.23 \pm 1.51$ \\
\hline IPL & $24.07 \pm 0.35(d)$ & $21.19 \pm 0.96$ & $24.12 \pm 0.42(\mathrm{~d})$ & $17.63 \pm 0.75$ & $25.57 \pm 1.60$ & $23.96 \pm 1.30$ \\
\hline GCL & $8.99 \pm 0.50(e)(f)$ & $7.28 \pm 0.63(\mathrm{~g})$ & $9.17 \pm 044(\mathrm{e})(\mathrm{h})$ & $7.73 \pm 0.71$ & $8.95 \pm 0.58(f)(h)$ & $7.33 \pm 0.64(\mathrm{~g})$ \\
\hline NFL & $10.09 \pm 0.61$ & $5.92 \pm 0.36$ (i) (j) & $8.45 \pm 0.66$ & $5.82 \pm 0.33(\mathrm{i})(\mathrm{k})$ & $7.63 \pm 0.70$ & $5.84 \pm 0.39(\mathrm{j})(\mathrm{k})$ \\
\hline
\end{tabular}

Thickness of the retinal layers ( $\mu \mathrm{m} \pm$ standard deviation); PS = photoreceptor outer and inner segment, $\mathrm{ONL}=$ outer nuclear layer, $\mathrm{OPL}=$ outer plexiform layer, INL = inner nuclear layer, IPL = inner plexiform layer, GCL = ganglion cell layer, NFL = nerve fiber layer, SD = standard deviation; $*$ the total retinal thickness was measured without counting the retinal pigment epithelium; The same letters in the same line means that there was no significant difference between those pairs of parameters at $5 \%$ of significance level using Student's t test; P values: $a=0.195, b=0.207, c=0.678, d=0.490, e=0.062, f=0.736$, $\mathrm{g}=0.758, \mathrm{~h}=0.058, \mathrm{i}=0.139, \mathrm{j}=0.330, \mathrm{k}=0.809$. 


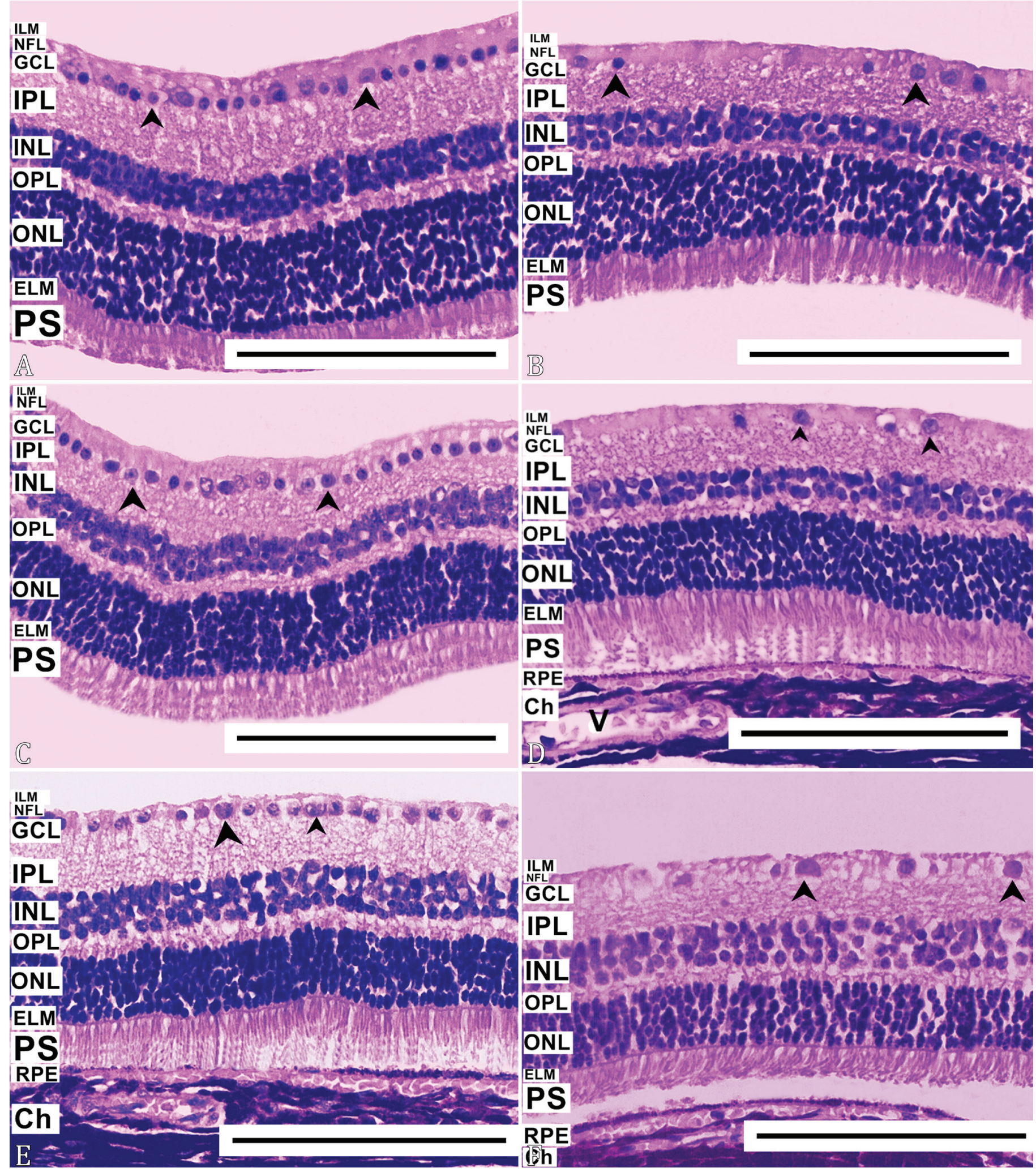

Fig.3. Photomicrographs of cross sections of the retinas of (A,B) Artibeus lituratus, (C,D) Artibeus planirostris and (E,F) Artibeus obscurus. $(\mathbf{A}, \mathbf{C}, \mathbf{E})$ from the central retina and (B,D,F) from the peripheral retina. Inner limiting membrane (ILM), nerve fiber layer (NFL), ganglion cell layer (GCL), inner plexiform layer (IPL), inner nuclear layer (INL), outer plexiform layer (OPL), outer nuclear layer (ONL), external limiting membrane (ELM), photoreceptor outer and inner segments (PS), retinal pigment epithelium (RPE), choroid (Ch), venule (V), retinal ganglion cells (arrowhead). HE, obj.40x, bar $=100 \mu \mathrm{m}$. 
significantly higher for the species A. lituratus in the central region, while in the peripheral region there was no significant difference of this layer between any species (Table 2). On the photoreceptors layer was observed rods and cones cells. This layer has a rod-like dominance for all three species, mainly in the peripheral region of the retina, where its outer segments are thin and long. In contrast, cones were found in abundance within the central region presenting its outer segments wide and short, with a progressive decrease in amount over to the peripheral region of the retina. The external limiting membrane and the retinal pigment epithelium were easily identified in the retina of all three bats (Fig.3).

The outer nuclear layer (ONL) is thicker in the central area compared to the peripheral regions of the retina in the three species of Artibeus (Table 2). However, the ONL in the central region of the retina of $A$. lituratus is the thickest layer between the bats being formed by approximately 10 layers of photoreceptors nuclei, while the species A. planirostris showed an intermediate thickness with an average of nine layers of photoreceptors nuclei and the species $A$. obscurus presented the lowest thickness in this area with approximately seven layers of photoreceptors nuclei (Fig.3).

The outer plexiform layer (OPL) was the only retinal layer that showed thicker in the peripheral region for the three bats. Subsequently, the inner nuclear layer (INL) is formed by the nuclei of the horizontal cells, bipolar cells, amacrine cells, and nuclei of Müller cells (Park et al. 2017). Nevertheless, immunohistochemical analysis is required for the differentiation of these cells (Fig.3). The species $A$. planirotris showed the highest thickness of the (INL) and $A$. lituratus exhibited the lowest thickness of this retinal area. In contrast, the inner plexiform layer (IPL) was slightly thicker in the central and peripheral retina of the species $A$. obscurus compared to the other two (Table 2).

The ganglion cell layer in the three species of Artibeus is formed by only one layer of RGCs. These cells are irregular and have large sizes, containing granules in the cytoplasm, and have a well-stained nucleus with a prominent nucleolus (Fig.2). As observed in the topographic map of density and distribution of these cells, a high density of RGCs was verified in the central region of the retina, a moderate density is located at the transition between the central and peripheral regions of this tunic and a low density of RGCs was observed in the peripheral region of the retina of the three bat species (Fig.1).

The last parameter measured was the nerve fiber layer (NFL). This layer is composed of the axons from the RGCs that converge and unite to form the optic nerve at the posterior region of the eyes. This layer is significantly thicker in the central region of the retina for all three species. However, $A$. lituratus exhibited the highest thickness of the (NFL) in the central area of the retina compared among them, and there were no significant differences in the peripheral region of the retina between the three species (Table 2). Furthermore, the retinas of the three bats showed a well-defined inner limiting membrane (Fig.3).

\section{DISCUSSION}

\section{Retinal ganglion cells distribution and visual acuity}

According to the isodensity topographic map from the three species of Artibeus studied, it was possible to detect a horizontal visual streak with a high concentration of retinal ganglion cells (Fig.1). This characteristic is a type of retinal specialization that is responsible for increasing the spatial resolution across the horizon (Hughes 1977, Collin 1999). Species that have a horizontal visual streak in the retina generally live in open fields, have a great capacity to move over long distances, and tend to have their eyes located more laterally in relation to the head (Hughes 1977, Provis 1979, Oyster et al. 1981, Moore et al. 2012). The horizontal visual streak makes the animals able to scan the environment constantly using a monocular vision system with a very few head and eyes movements, which the field of view concentrate mainly on the horizon (Shinozaki et al. 2010, Coimbra et al. 2017). Furthermore, this is an especially useful feature for detecting predators (Hughes 1977).

This type of retinal specialization found in the retina is directly related to the behavior of these bats. Morrison (1980) studied the foraging behavior of $A$. lituratus and he observed that this species usually stays in the trees during the day and constantly changes the locations within an area ranging from 0.5 to 2.5 hectares. Moreover, this species changes the eating behavior according to the moon phases. During nights when full moons occur, feeding and agglomeration times decrease on the trees in order to avoid being perceived by predators such as owls. Gutierrez et al. (2014) performed behavioral tests with the same species referring to feeding ability in different luminosities. They have found that the species $A$. lituratus takes a long time to detect its targets with a high light intensity similar to twilight and this may be related to an exacerbated exposure to predators during this period of high luminosity. On the other hand, these bats were quite effective in detecting targets with an illumination similar to the full moon. In addition, the eyes of these three bats are located more laterally in relation to the head (Guerrero et al. 2003, Araújo \& Langguth 2010) and these bats move both in open areas and dense forests during their foraging time (Bernard \& Fenton 2003, Menezes Jr et al. 2008). All those behavioral characteristics are in agreement with our findings regarding the type of retinal specialization detected for these bats of the genus Artibeus, which is mainly related to the detection of either predators or food resources.

In animals that have a horizontal visual streak, the retina tends to present a central area of maximum density of RGCs in the temporal quadrant, especially in animals that have their eyes located more laterally (Hughes 1977). This central area was observed in the inferotemporal quadrant of the retina of the three bats and it has been characterized as areae centrales. This feature was also found in bats species of flying foxes, such as Pteropus giganteus, Pteropus poliocephalus, Pteropus poliocephalus, Megaloglossus woermanni, Scotonyceteris zenkeri, Casynicteris argynnis, Rousettus aegyptiacus, Epomophorus wahlbergi, Epomops franqueti, Eidolon helvum, Eidolon helvum and Hypsignathus monstrosus and some echolocating bats: Rhinolophus rouxi, Rhinolophus ferrumequinum, Nyctophilus gouldi, Taphozous georgianus, Megaderma lyra, Dermanura cinerea, Macroderma gigas, Phyllostomus hastatus, Phyllostomus discolor and Artibeus jamaicensis (Pedler \& Tilley 1969, Pettigrew et al. 1988, Neuweiler 2000, Heffner et al. 2001, 2007, 2008, Müller et al. 2007, Kim et al. 2008, Hoffmann et al. 2016, Coimbra et al. 2017). The areae centrales provides a high-resolution vision in this point of the retina, frontal discrimination towards the horizon, and a type of binocular 
fixation (Rapaport \& Stone 1984). A high spatial resolution and frontal discrimination of the field of view are particularly important for fruit-eating bats, including those of the genus Artibeus, that need to detect their food resources located in fruit trees just in front of them.

The species A. lituratus showed an extra horizontal visual streak connected and a circular area with a high density of RGCs. According to Shinozaki et al. (2010) areas of high density of RGCs outside the horizontal visual streak might enhance the visual resolving power of the animal and increase the frontal field of view to discriminate objects. These characteristics in the retina of $A$. lituratus suggest that these bats have a wider field of view among these three species within the genus Artibeus.

The visual acuity of the three species of Artibeus was considered high when compared to other echolocating bats. Thus, A. lituratus exhibited the highest visual acuity among the three species. However, the other two species also showed a good spatial resolving power compared to other bats from different genera. The visual capability of bats is directly related to the food pattern of each species (Chase 1981, Rydell \& Eklöf 2003). Bats that have a greater visual acuity tend to be frugivorous, such as flying foxes that present a high visual acuity ranging from 2.2 cycles/degree to 5.5 cycles/degree (Pedler \& Tilley 1969, Neuweiler 2000, Heffner et al. 2008, Müller et al. 2007, Coimbra et al. 2017) and some echolocating fruit-eating bats, for instance, the three species of Artibeus studied, A. lituratus (1.92 cycles/degree), A. planirostris $(1.77$ cycles/degree) and A. obscurus $(1.50$ cycles/degree), A. jamaicensis (1.1 cycles/degree) (Heffner et al. 2001), D. cinerea (1.35 cycles/degree), T. georgianus (1.3 cycles/degree) and P. hastatus (1.2 cycles/degree) (Pettigrew et al. 1988). In addition, large carnivorous bats such as M. gigas (1.9 cycles/degree) and M. lyra (1.5 cycles/ degree) show a high visual acuity among the echolocating bats as well (Pettigrew et al. 1988). Omnivorous species as $P$. hastatus (1.2 cycles/degree) (Heffner et al. 2007) and P. discolor (1.7 cycles/degree) (Hoffmann et al. 2016) also have a high visual acuity. In contrast, insectivorous species tend to have a lower visual acuity among the echolocating bats, for example, the species $R$. rouxi $(0.35$ cycles/degree) and Eptesicus nilssonii (0.6 cycles/degree) and in particular insectivorous bats of the family Vespertilionidae, including Myotis brandtii, Myotis lucifugus, Myotis mystacinus and Myotis daubentonii ( 0.3 cycles/degree) (Rydell \& Eklöf 2003, Eklöf \& Jones 2003, Feller et al. 2009, Eklöf et al. 2014). Furthermore, frugivorous bats exhibit a better morphological adaptation for low light vision compared to strictly insectivorous bats (Suthers 1966, Suthers et al. 1969, Sadier et al. 2018).

According to Veilleux \& Kirk (2014), the evolution of visual acuity in certain groups of mammals is related to the high dependency of vision on basic ecological behaviors, including foraging techniques, migratory behavior, shelter locations and to avoid predators. However, for echolocating bats, the evolutionary pattern of vision differs from the general pattern observed in mammals. The visual system of bats is directly related to the evolutionary process of echolocation (Gutierrez et al. 2018a, 2018b). This sense has been acquired most recently among bats and the most ancestral bats on the evolutionary scale used to be more vision-dependent (Jones \& Teeling 2006, Teeling 2009, Thiagavel et al. 2018). Boonman et al. (2013) stated that echolocating bats constantly integrate information acquired by echolocation and vision, and that, this sense of echolocation was refined to detect increasingly smaller targets in association with the use of vision, especially for insectivorous bats. Although it has been shown that echolocating bats use both vision and echolocation to locate objects, divert obstacles and to control their approach to the food site (Rother \& Schmidt 1982, Joermann et al. 1988, Eklöf \& Jones 2003, Orbach \& Fenton 2010), gleaning (frugivorous) bats detects and find their food foraging in the passive mode using other sensory cues (olfactory and visual) rather than by echolocation (Kalko \& Schnitzler 1998, Gutierrez et al. 2018a).

Bats that have a sophisticated echolocation system tend to exhibit a less developed visual capability, such as insectivorous bats which detect small prey. On the other hand, bats with a good visual acuity tend to have less dependence on echolocation, for example, frugivorous and nectarivorous bats that can distinguish brightness and spectral composition to find different food items (Pedler \& Tilley 1969, Pettigrew et al. 1988, Neuweiler 2000, Heffner et al. 2001, Winter et al. 2003, Kim et al. 2008, Müller et al. 2009, Eklöf et al. 2014, Coimbra et al. 2017, Sadier et al. 2018, Simões et al. 2018, Gutierrez et al. 2018b, Kries et al. 2018). These statements corroborate our findings, in which the three species of the genus Artibeus showed a high visual acuity. Therefore, the visual capability is related to the echolocation system and also to the feeding guild that each bat belongs to. These characteristics of echolocation and vision apply to fruit-eating bats, and it was observed in a behavioral experiment performed by Gutierrez et al. (2014) showed that the species A. lituratus used visual clues to find food resources instead of echolocation.

Another important fact observed in this study is that even bats of different species belonging to the same genus and with similar eating habits, they exhibit different values of visual acuity (Table 1). This feature may be related to the size of the body of each bat and consequently to the size of their eyes that influences the value of retinal magnification factor (RMF) (Blackwood et al. 2010, Eklöf et al. 2014, Veilleux \& Kirk 2014). This relation was observed at least among the three species of the genus Artibeus studied. The species $A$. lituratus, which has a total length ranging from 8.6-12 $\mathrm{cm}$ and an average bodyweight of $75 \mathrm{~g}$ (Guerrero et al. 2003, Araújo \& Langguth 2010) showed the highest visual acuity and the highest RMF $(33.66 \mu \mathrm{m} /$ degree), while the species $A$. planirostris that has a total length ranging from $7.5-11 \mathrm{~cm}$ and body mass between 40-69g (Vizotto \& Taddei 1973, Hollis 2005) exhibited an intermediate value of visual acuity and RMF $(31.92 \mu \mathrm{m} /$ degree $)$ between the three species and the species A. obscurus that exhibits an average length of approximately $7.9 \mathrm{~cm}$ and body mass between $28-52.2 \mathrm{~g}$ (Marques-Aguiar 1994, Haynes \& Lee Jr 2004) showed the lowest visual acuity and the RMF $(26.86 \mu \mathrm{m} /$ degree $)$ among them. Thus, the visual acuity and the retinal magnification factor tends to be higher in those species that present larger body size and bigger eyes, at least among those bats which belong to the same genus. However, according to Eklöf et al. (2014), it is neither a rule nor a distinctive pattern.

According to Denzinger \& Schnitzler (2013) species of bats with similar adaptations are attributed to the same guilds. Bats that exploit the same types of environmental resources tend to share morphological adaptations regardless of its 
phylogeny. This can be demonstrated in the case of those bats of different genera and even of different families that share similar visual acuity values and explore the same food resources. Therefore, it was observed for the bats of the genus Artibeus of this study that present similar visual acuity to other frugivorous bats.

\section{Retinal morphometry}

The retinas of the three species of Artibeus are avascular and this characteristic is in agreement with Bojarski \& Bernard (1988) and Neuweiler (2000) who claimed that echolocating bats usually exhibit avascular retinas and the nutrition of this tunic comes exclusively from the blood supply of the choroid and partly from the vitreous body. Moreover, the retinas of the three species studied did not show tapetum lucidum, corroborating Ollivier et al. (2004) and Moritz et al. (2013) who concluded that only flying foxes present this structure and microchiropteran bats do not have this reflective membrane and that it is not an indispensable feature for the eyes of nocturnal animals. Furthermore, the relationship between the size of the retinal area and eye axial length was directly proportional for the three species of bats, where the retinal area showed larger for $A$. lituratus and shorter for $A$. obscurus. These morphometric data follow the statements of Blackwood et al. (2010) who say that the retinal area is directly proportional to the size of the eye and its axial length, even to those bats that belong to the same genus.

Regarding to the total thickness of the retinas, it was observed that the retina of $A$. lituratus is thicker in comparison with the other two (Table 2). However, the thicknesses of the retinas for the three species are within the range of variances for echolocating bats, which range between 100 and $150 \mu \mathrm{m}$ (Wassle \& Boycott 1991, Neuweiler 2000). In addition, all three species presented the central region of the retina thicker than the peripheral area, and it is due to this region be more important to vision, presenting the highest density of RGCs, photoreceptors and other neurons in general (Pettigrew et al. 1988, Collin 2008, Moore et al. 2012).

The prevalence of rods, mainly in the peripheral area of the retina, highlights the importance of these cells to the nocturnal activity of bats (scotopic vision). On the other hand, it was observed a greater abundance of cones in the central region of the retina indicating the capacity for color perception by these bats of the genus Artibeus. Müller et al. (2007) and Feller et al. (2009) observed the same pattern of distribution of photoreceptors in the retina in other echolocating bats. However, to determine the sensitivity of a cone to a specific wavelength, either immunohistochemical or electroretinographic tests are required. Echolocating bats and flying foxes are classified as dichromatic mammals having two types of visual pigments related to color perceptions, cone opsin (S-) and cone opsin (L-) which are associated with the sensitivity to short wavelength and medium-long wavelength, respectively (Hope \& Bhatnagar 1979, Müller et al. 2007, Feller et al. 2009, Sadier et al. 2018, Simões et al. 2018, Gutierrez et al. 2018b, Kries et al. 2018). In addition, some species of nectarivorous bats show sensitivity to ultraviolet wavelength with sensitivity peaks at $365 \mathrm{~nm}$ and have cones that coexpress the opsins $\mathrm{S}$ and $\mathrm{L}$ (Winter et al. 2003, Müller et al. 2009).
The average number of photoreceptors nuclei layers might be directly related to the size of the outer nuclear layer (ONL). The species A. lituratus showed 10 layers of nuclei and the thickest ONL, while the species A. obscurus exhibited 07 layers of nuclei and the lowest thickness of the ONL. Ghassemi \& Gholami (2015) observed that the species Rhinopoma hardwickii has 08 layers of photoreceptors nuclei in the retina, even it being an insectivorous species of large size. Therefore, the number of photoreceptors nuclei layers varies according to the species, but it tends to be higher for frugivorous bats (Blackwood et al. 2010).

The three species of bats exhibited a smaller thickness of the outer plexiform layer (OPL) in the central region of the retina by cause of the axons of the photoreceptors, essentially formed by rods, are shorter in this region due to this area be more sensitive to light (Masland 2001, Kolb et al. 2001). Although the inner nuclear layer (INL) was thicker in the central region of the retina of A. planirostris and A. obscurus, it is not a discrepant difference (Table 2). The inner plexiform layer (IPL) showed much thicker than the outer plexiform layer with little variations among the species of Artibeus studied. This layer is thicker than the OPL because it is the site of synapses between bipolar neurons and ganglion cells mediated by amacrine cells (Wassle \& Boycott 1991, Rodrigues 2010).

The ganglion cell layer (GCL) exhibited a difference in the total number and density of RGCs among the three species (Table 1). This layer showed significantly thicker in the central region for all bats, remaining constant throughout the retina until decreasing its thickness in the peripheral area (Table 2). Furthermore, the quantity of RGCs was higher in the central area of the retina compared to the periphery as well (Fig.1). These data reinforce the idea of photoreceptor-RGCs proportions suggested by Collin (2008) and Hauzman et al. (2014) where the area of the retina that presents the highest density of RGCs will also have a higher density of cones and consequently a greater visual acuity and this characteristic was evidenced for the species of Artibeus in this study. The RGCs presented cell bodies of different sizes, which suggests that there are different types of RGCs in the retina of these bats (Fig.2). This differentiation in size and types of RGCs was also evidenced by Oyster et al. (1981), Pettigrew et al. (1988), Dacheux \& Raviola (1994), and Brooks et al. (1999). Regarding the estimation of the total number of RGCs, which varied significantly between the three species even belonging to the same genus (Table 1), it may be directly related to the retinal area and eye size (Blackwood et al. 2010, Eklöf et al. 2014).

Finally, the thickness of the nerve fiber layer (NFL) for the three bats followed the pattern of vertebrate animals observed, where the retinal NFL thickness decreases from the optic disk (central region) toward the periphery of the retina following the decrease in the number of RGCs (Qijiu et al. 1981, Brooks et al. 1999). As a consequence of the greater number of RGCs in the central retina, the NFL of the species A. lituratus reveled thicker in this region, whereas A. obscurus showed the smallest thickness among these bats. In contrast, there was no significant difference in the thickness of this layer in the peripheral region between the three species of Artibeus, probably due to the low density of RGCs in this area (Table 2).

These histomorphometric data corroborate the information suggested by Jolicoeur \& Baron (1980) who claimed that 
frugivorous bats have larger eyes and a greater visual capability compared to insectivorous species. In addition, the visual capacity of echolocating bats is directly associated with the echolocation system and related to the eating habits of each species (Rydell \& Eklöf 2003, Boonman et al. 2013, Denzinger \& Schnitzler 2013). Regarding the fruit-eating bats that exhibit a good visual acuity and color perception, Veilleux \& Kirk (2014) concluded that these visual features make those animals able to improve the success of foraging, feeding on specific fruits and increases the success in locating shelters and the chances to detect predators. Therefore, such evidence suggests that vision plays a very important role for these three fruit-eating bats of the genus Artibeus.

\section{CONCLUSION}

Bats of the genus Artibeus have a high visual acuity compared to other echolocating bats already described in the literature. The morphophysiological differences found between the retinas of the three bats might be related mainly due to the number of neurons, especially of retinal ganglion cells (RGCs), and the size of the eyes that consequently influenced in the retinal magnification factor (RMF) resulting in different values of visual acuity. The species Artibeus lituratus exhibited the greatest values of visual acuity and the highest number of RGCs distributed throughout the retina being arranged in a horizontal visual streak in the central area. The other two species showed a similar pattern of cell distribution, but the species Artibeus obscurus showed the lowest values of visual acuity and number of RGCs, whereas the species Artibeus planirostris demonstrated intermediate values of these parameters. In addition, we presuppose that all these differences among the three species may be also directly linked to the phylogeny of the genus.

Acknowledgements.- To the "Coordenação de Aperfeiçoamento de Pessoal de Nível Superior" (CAPES), for granting the financial support for the development of this study.

Conflict of interest statement.- The authors declare no conflict of interest.

\section{REFERENCES}

Altringham J.D. 2011. Echolocation and other senses, p.61-96. In: Altringham J.D. (Ed.), Bats: from conservation to ecology. 2nd ed. Oxford University Press, Oxford.

Araújo P. \& Langguth A. 2010. Caracteres distintivos das quatro espécies de grandes Artibeus (Phyllostomidae) de Paraíba e Pernambuco, Brasil. Chiropt. Neotrop. 16(2):715-722.

Bernard E. \& Fenton M.B. 2003. Bat mobility and roosts in a fragmented landscape in Central Amazonia, Brazil. Biotropica. 35(2):262-277. <https:// dx.doi.org/10.1111/j.1744-7429.2003.tb00285.x>

Blackwood S.E., Plummer C.E., Crumley W., Mackay E.O., Brooks D.E. \& Barrie K.P. 2010. Ocular parameters in a captive colony of fruit bats. Vet. Ophthalmol. 13(supl.):72-79. <https://dx.doi.org/10.1111/j.1463-5224.2010.00816. $\mathrm{x}><$ PMid:20840093>

Bojarski C. \& Bernard R.T.F. 1988. Comparison of the morphology of the megachiropteran and microchiropteran eye. S. Afr. J.Zool. 23(3):155-160. <https://dx.doi.org/10.1080/02541858.1988.11448095>

Bôlla D.A., Carvalho F., Gazarini J., Zocche J.J. \& Pedro W.A. 2018. Variação na dieta de Artibeus lituratus e Sturnira lilium (Chiroptera: Phyllostomidae) em três regiões fitogeográficas no sul do Brasil. Mastozool. Neotrop. 25(1):516. <https://dx.doi.org/10.31687/saremMN.18.25.1.0.02>
Boonman A., Bar-on Y., Cvikel N. \& Yovel Y. 2013. It's not black or white - on the range of vision and echolocation in echolocating bats. Front. Physiol. 4:248. <https://dx.doi.org/10.3389/fphys.2013.00248><PMid:24065924>

Brooks D.E., Komàromy A.M. \& Källberg M.E. 1999. Comparative retinal ganglion cell and optic nerve morphology. Vet. Ophthalmol. 2(1):3-11. <https://dx.doi.org/10.1046/j.1463-5224.1999.00047.x><PMid:11397238>

Chase J. 1981. Visually guided escape responses of microchiropteran bats. Anim. Behav. 29(3):708-713. <https://dx.doi.org/10.1016/S00033472(81)80005-X>

Coimbra J.P., Nolan P.M., Collin S.P. \& Hart N. 2012. Retinal ganglion cell topography and spatial resolving power in penguins. Brain Behav. Evol. 80(4):254-268. <https://dx.doi.org/10.1159/000341901><PMid:23038153>

Coimbra J.P., Pettigrew J.D., Kaswera-Kyamakya C., Gilissen E., Collin S.P. \& Manger P.R. 2017. Retinal ganglion cell topography and spatial resolving power in African megachiropterans: Influence of roosting microhabitat and foraging. J. Comp. Neurol. 525(1):186-203. <https://dx.doi.org/10.1002/ cne.24055>

Collin S.P. \& Pettigrew J.D. 1988. Retinal ganglion cell topography in teleosts: a comparison between Nissl-stained material and retrograde labelling from the optic nerve. J. Comp. Neurol. 276(3):412-422. <https://dx.doi. org/10.1002/cne.902760306><PMid:2461397>

Collin S.P. 1988. The retina of the shovel-nosed ray, Rhinobatos batillum (Rhinobatidae): morphology and quantitative analysis of the ganglion, amacrine and bipolar cell populations. Exp. Biol. 47(4):195-207. <PMid:3220121>

Collin S.P. 1999. Behavioural ecology and retinal cell topography, p.509-535. In: Archer S.N., Djamgoz M.B.S., Loew E.R., Partridge J.C. \& Vellarga S. (Eds), Adaptive Mechanisms in the Ecology of Vision. Springer, Dordrecht.

Collin S.P. 2008. A web-based archive for topographic maps of retinal cell distribution in vertebrates. Clin. Exp. Optom. 91(1):85-95.<https://dx.doi. org/10.1111/j.1444-0938.2007.00228.x><PMid:18045254>

Cunningham J.G. 2004. 0 sistema visual, p.91-97. In: Cunningham J.G. (Ed.), Tratado de Fisiologia Veterinária. $3^{\mathrm{a}}$ ed. Guanabara Koogan, Rio de Janeiro.

Dacheux R.F. \& Raviola E. 1994. Functional anatomy of the neural retina, p.285-309. In: Dacheux R.F. \& Raviola E. (Eds), Principles and Practice of Ophthalmology: Basic Sciences. Vol.1. W.B. Saunders, Philadelphia.

Denzinger A. \& Schnitzler H.U. 2013. Bat guilds, a concept to classify the highly diverse foraging and echolocation behaviors of microchiropteran bats. Front. Physiol. 4:9-23. <https://dx.doi.org/10.3389/fphys.2013.00164> $<$ PMid:23840190>

Eklöf J. \& Jones G. 2003. Use of vision in prey detection by brown long-eared bats, Plecotus auritus. Anim. Behav. 66(5):949-953. <https://dx.doi. org/10.1006/anbe.2003.2272>

Eklöf J., Šuba J., Petersons G. \& Rydell J. 2014. Visual acuity and eye size in five European bat species in relation to foraging and migration strategies. Environ. Exp. Biol. 12(1):1-6.

Feller K.D., Lagerholm S., Clubwala R., Silver M.T., Haughey D., Ryan J.M., Loew E.R., Deutschland M.E. \& Kenyon K.L. 2009. Characterization of photoreceptor cell types in the little brown bat Myotis lucifugus (Vespertilionidae). Comp. Biochem. Physiol. B, Biochem. Mol. Biol. 154(4):412-418. <https://dx.doi. org/10.1016/j.cbpb.2009.08.006><PMid:19720154>

Ferreira W.A.S., Borges B.N., Rodrigues-Antunes S., Andrade F.A.G., Aguiar G.F.S., Silva-Junior J.D.S., Marques-Aguiar S.A. \& Harada M.L. 2014. Phylogeography of the dark fruit-eating bat Artibeus obscurus in the Brazilian Amazon. J. Hered. 105(1):48-59. <https://dx.doi.org/10.1093/jhered/est066>

Galetti M. \& Morellato L.P.C. 1994. Diet of the large fruit-eating bat Artibeus lituratus in a forest fragment in Brasil. Mammalia 58(4):661-665. <https:// dx.doi.org/10.1515/mamm.1994.58>

Gardner A.L. 2008. Mammals of South America (Marsupials, Xenarthrans, Shrews, and Bats). Vol.1. The University of Chicago Press, Chicago. 669p. 
Garza-GisholtE., Kempster R.M., Hart N.S. \& Collin S.P. 2015. Visual specializations in five sympatric species of stingrays from the family Dasyatidae. Brain Behav. Evol. 85(4):217-232. <https://dx.doi.org/10.1159/000381091> $<$ PMid:26183463>

Ghassemi F. \& Gholami S. 2015. Comparative histomorphometrical study of retina in insectivorous bat (Rhinopoma hardwickii) and frugivorous bat (Roussetus aegyptiacus). Cibtech J. Zool. 4(3):27-34.

Gould E. 1977. Echolocation and Communication, p.247-279. In: Baker R.J., Jones J.K. \& Carter D.C. (Eds), Biology of Bats of The New World Family Phyllostomidae. Part II. Texas Tech Press, Lubbock, Texas.

Griffin D.R. 1970. Migration and homing of bats, p. 233-264. In: Wimsatt W.A. (Ed.), Biology of Bats. Vol.1. Academic Press, New York.

Guerrero J.A., Luna E. \& Sánchez-Hernández C. 2003. Morphometrics in the quantification of character state identity for the assessment of primary homology: an analysis of character variation of the genus Artibeus (Chiroptera: Phyllostomidae). Biol. J. Linn. Soc. 80(1):45-55. <https:// dx.doi.org/10.1046/j.1095-8312.2003.00218.x>

Gundersen H. J. G. 1977. Notes on the estimation of the numerical density of arbitrary profiles: the edge effect. J. microsc. 111(2):219-223. <https:// dx.doi.org/10.1111/j.1365-2818.1977.tb00062.x>

Gutierrez E.D.A., Castiglione G.M., Morrow J.M., Schott R.K., Loureiro L.O., Lim B.K. \& Chang B.S. 2018a. Functional shifts in bat dim-light visual pigment are associated with differing echolocation abilities and reveal molecular adaptation to photic-limited environments. Mol. Biol. Evol. 35(10):24222434. <https://dx.doi.org/10.1093/molbev/msy140><PMid:30010964>

Gutierrez E.D.A., Pessoa V.F., Aguiar L.M. \& Pessoa D.M. 2014. Effect of light intensity on food detection in captive great fruit-eating bats, Artibeus lituratus (Chiroptera: Phyllostomidae). Behav. Processes 109(PartA):64-69. <https://dx.doi.org/10.1016/j.beproc.2014.08.003>

Gutierrez E.D.A., Schott R.K., Preston M.W., Loureiro L.O., Lim B.K. \& Chang B.S. $2018 \mathrm{~b}$. The role of ecological factors in shaping bat cone opsin evolution. Proc. R. Soc. B 285:(1876)20172835. <https://dx.doi.org/10.1098/ rspb.2017.2835><PMid:29618549>

Harahush B.K., Hart N.S. \& Collin S.P. 2014. Ontogenetic changes in retinal ganglion cell distribution and spatial resolving power in the brownbanded bamboo shark Chiloscyllium punctatum (Elasmobranchii). Brain Behav. Evol. 83(4):286-300. <https://dx.doi.org/10.1159/000361036> $<$ PMid:24993335>

Hauzman E., Bonci D., Grotzner S., Mela M., Liber A., Martins S. \& Ventura D. 2014. Comparative study of photoreceptor and retinal ganglion cell topography and spatial resolving power in Dipsadidae snakes. Brain Behav. Evol. 84(3):197-213. <https://dx.doi.org/10.1159/000365275> $<$ PMid:25342570>

Haynes M.A. \& Lee Jr T.E. 2004. Artibeus obscurus. Mamm. Species (752):1-5. <https://dx.doi.org/10.1644/752>

Heffner R.S, Koay G. \& Heffner H.E. 2008. Sound localization acuity and its relation to vision in large and small fruit-eating bats: II. Non-echolocating species, Eidolon helvum and Cynopterus brachyotis. Hear. Res. 241(1/2):8086. <https://dx.doi.org/10.1016/j.heares.2008.05.001><PMid:18571883>

Heffner R.S., Koay G. \& Heffner H.E. 2001. Sound localization in a new-world frugivorous bat, Artibeus jamaicensis: acuity, use of binaural cues, and relationship to vision. J. Acoust. Soc. Am. 109(1):412-421. <https://dx.doi. org/10.1121/1.1329620><PMid:11206172>

Heffner R.S., Koay G. \& Heffner H.E. 2007. Sound-localization acuity and its relation to vision in large and small fruit-eating bats: I. Echolocating species, Phyllostomus hastatus and Carollia perspicillata. Hear. Res. 234(1/2):1-9. <https://dx.doi.org/10.1016/j.heares.2007.06.001> <PMid:17630232>

Hoffmann S., Vega-Zuniga T., Greiter W., Krabichler Q., Bley A., Matthes M., Zimmer U.F. \& Luksch H. 2016. Congruent representation of visual and acoustic space in the superior colliculus of the echolocating bat hyllostomus discolor. Eur. J. Neurosci. 44(9):2685-2697. <https://dx.doi.org/10.1111/ ejn.13394> <PMid:27600873>

Hollis L. 2005. Artibeus planirostris. Mamm. Species 775:1-6. <https://dx.doi. org/10.1644/1545-1410(2005)775[0001:AP]2.0.CO;2>

Hope G.M. \& Bhatnagar K.P. 1979. Electrical response of bat retina to spectral stimulation: comparison of four microchiropteran species. Experientia 35(9):1189-1191.<https://dx.doi.org/10.1007/BF01963279><PMid:488274>

Hughes A. 1977. The topography of vision in mammals of contrasting life style: comparative optics and retinal organization, p.613-756. In: Crescitelli F. (Ed.), Handbook of Sensory Physiology. Vol.VII/5. Springer-Verlag, Berlin.

Hughes A. 1981. Population magnitudes and distribution of the major modal classes of cat retinal ganglion cell as estimated from HRP filling and a systematic survey of the soma diameter spectra for classical neurones. J. Comp. Neurol. 197(2):303-339. <https://dx.doi.org/10.1002/ cne.901970209><PMid:7276237>

Joermann G., Schmidt U. \& Schmidt C. 1988. The mode of orientation during flight and approach to landing in two phyllostomid bats. Ethology 78(4):332340. <https://dx.doi.org/10.1111/j.1439-0310.1988.tb00242.x>

Jolicoeur P. \& Baron G. 1980. Brain center correlations among Chiroptera. Brain Behav. Evol. 17(6):419-431. <https://dx.doi.org/10.1159/000121812> <PMid:7437897>

Jones G. \& Teeling E.C. 2006. The evolution of echolocation in bats. Trends Ecol. Evol. 21(3):149-156.<https://dx.doi.org/10.1016/j.tree.2006.01.001> $<$ PMid:16701491>

Kalko E.K.V. \& Schnitzler H.U. 1998. How echolocating bats approach and acquire food, p.197-204. In: Kunz T.H. \& Racey P.A. (Eds), Bat Biology and Conservation. Smithsonian Institution Press, Washington D.C.

Kim T.J., Jeon Y.K., Lee J.Y., Lee E.S. \& Jeon C.-J. 2008. The photoreceptor populations in the retina of the greater horseshoe bat Rhinolophus ferrumequinum. Mol. Cells 26(4):373-379. <PMid:18612246>

Koay G., Bitter K.S., Heffner H.E. \& Heffner R.S. 2002. Hearing in American leaf-nosed bats. I: Phyllostomus hastatus. Hear. Res. 171(1/2):96-102. <https://dx.doi.org/10.1016/s0378-5955(02)00458-6><PMid:12204353>

Kolb H., Nelson R., Ahnelt P. \& Cuenca N. 2001. Cellular organization of the vertebrate retina. Prog. Brain Res. 131:3-26. <https://dx.doi.org/10.1016/ s0079-6123(01)31005-1><PMid:11420950>

Koopman K.F. 1982. Biogeography of the bats of South America, p.273302. In: Mares M.A. \& Genoways H.H. (Eds), Mammalian Biology in South America. Vol.6. Special Publication Series Pymatunig Laboratory of Ecology, University of Pittsburgh, Pittsburgh.

Kries K., Barros M.A., Duytschaever G., Orkin J.D., Janiak M.C., Pessoa D.M. \& Melin A.D. 2018. Colour vision variation in leaf-nosed bats (Phyllostomidae): links to cave roosting and dietary specialization. Mol. Ecol. 27(18):36273640. <https://dx.doi.org/10.1111/mec.14818> <PMid:30059176>

Leite A.G.B., Oliveira D. \& Baraldi-artoni S.M. 2013. Morfologia do sistema ocular dos animais domésticos. Ars Vet. 29(1):42-51.

Lim B.K., Engstrom M.D., Lee T.E., Patton J.C. \& Bickham J.W. 2004. Molecular differentiation of large species of fruit-eating bats (Artibeus) and phylogenetic relationships based on the cytochrome b gene. Acta Chiropt. 6(1):1-12. <https://dx.doi.org/10.3161/1508110042176699>

Lisney T.J., Iwaniuk A.N., Kolominsky J., Bandet M.V., Corfield J.R. \& Wylie D.W. 2012. Interspecifc variation in eye shape and retinal topography in seven species of galliform bird (Aves: Galliformes: Phasianidae). J. Comp. Physiol. A Neuroethol. Sens. Neural. Behav. Physiol. 198(10):717-731. <https://dx.doi.org/10.1007/s00359-012-0742-1> <PMid:22806571>

Marques-Aguiar S.A. 1994. A Systematic review of the large species of Artibeus Leach, 1821 (Mammalia: Chiroptera), with some phylogenetic inferences. Bol. Mus. Para. Emílio Goeldi, Zool. 10(1):3-83. 
Martins M.V., Torres J.M. \& dos Anjos E.A.C. 2014. Dieta de morcegos frugívoros em remanescente de Cerrado em Bandeirantes, Mato Grosso do Sul. Biotemas 27(2):129-135. <https://dx.doi.org/10.5007/21757925.2014v27n2p129>

Masland R.H. 2001. The fundamental plan of the retina. Nat. Neurosci. 4(9):877-886. <https://dx.doi.org/10.1038/nn0901-877><PMid:11528418>

Menezes Jr L.F., Duarte A.C., Novaes R.L.M., Façanha A.C., Peracchi A.L., Costa L.D.M., Dias e Fernandes A.F.P. \& Esbérard C.E.L. 2008. Movement of Artibeus lituratus (Olfers, 1818) (Mammalia, Chiroptera) between island and continent on State of Rio de Janeiro, Brazil. Biota Neotrop. 8(2):243-245. <https://dx.doi.org/10.1590/S1676-06032008000200021>

Mikich S.B. 2002. A dieta dos morcegos frugívoros (Mammalia, Chiroptera, Phyllostomidae) de um pequeno remanescente de Floresta Estacional Semidecidual do sul do Brasil. Revta Bras. Zool. 19(1):239-249. <https:// dx.doi.org/10.1590/S0101-81752002000100023>

Moore B.A., Kamilar J.M., Collin S.P., Bininda-Emonds O.R.F., Dominy N.J., Hall M.I., Heesy C.O., Johnsen S., Lisney T.J., Loew E.R., Moritz G., Nava S.S., Warrant E., Yopak K.E. \& Fernández-Juricic E. 2012. A novel method for comparative analysis of retinal specialization traits from topographic maps. J. Vis. 12(12):1-24. <https://dx.doi.org/10.1167/12.12.13><PMid:23169995>

Morais D.B., Paula T.A., Barros M.S., Balarini M.K., Freitas M.B. \& Matta S.L. 2013. Stages and duration of the seminiferous epithelium cycle in the bat Sturnira lilium. J. Anat. 222(3):372-379. <https://dx.doi.org/10.1111/ joa.12016><PMid:23305159>

Moritz G.L., Lim N.T.L., Neitz M., Peichl L. \& Dominy N.J. 2013. Expression and evolution of short wavelength sensitive opsins in colugos: a nocturnal lineage that informs debate on primate origins. Evol. Biol. 40(4):542-553. <https://dx.doi.org/10.1007/s11692-013-9230-y><PMid:24293738>

Morrison D.W.1980. Foraging and day-roosting dynamics of canopy fruit bats in Panama. J. Mammal. 61(1):20-29. <https://dx.doi.org/10.2307/1379953>

Moshfeghi D.M., Moshfeghi A.A. \& Finger P.T. 2000. Enucleation. Surv. Ophthalmol. 44(4):277-301. <https://dx.doi.org/10.1016/s0039-6257(99)00112-5> $<$ PMid:10667436>

Müller B., Glösmann M., Peichl L., Knop G.C., Hagemann C. \& Ammermüller J. 2009. Bat eyes have ultraviolet-sensitive cone photoreceptors. PLoS One 4(7):e6390. <https://dx.doi.org/10.1371/journal.pone.0006390> $<$ PMid:19636375>

Müller B., Goodman S.M. \& Peichl L. 2007. Cone photoreceptor diversity in the retinas of fruit bats (Megachiroptera). Brain Behav. Evol. 70(2):90-104. <https://dx.doi.org/10.1159/000102971><PMid:17522478>

Neuweiler G. 2000. Vison, olfaction and taste, p.210-233. In: Neuweiler G. (Ed.), The Biology of Bats. Oxford University Press, New York.

Oliveira A.K.M. \& Lemes F.T.F. 2010. Artibeus planirostris como dispersor e indutor de germinação em uma área do Pantanal do Negro, Mato Grosso do Sul, Brasil. Revta Bras. Biociênc. 8(1):49-52.

Ollivier F.J., Samuelson D.A., Brooks D.E., Lewis P.A., Kallberg M.E. \& Komaromy A.M. 2004. Comparative morphology of the tapetum lucidum (among selected species). Vet. Ophthalmol. 7(1):11-22. <https://dx.doi. org/10.1111/j.1463-5224.2004.00318.x> <PMid:14738502>

Oprea M., Brito D., Vieira T.B., Mendes P., Lopes S.R., Fonseca R.M., Coutinho R.Z. \& Ditchfield A.D. 2007. A note on the diet and foraging behavior of Artibeus lituratus (Chiroptera, Phyllostomidae) in an urban park in southeastern Brazil. Biota Neotrop. 7(2):297-300. <https://dx.doi.org/10.1590/S167606032007000200033>

Orbach D.N. \& Fenton M.B. 2010. Vision impairs the abilities of bats to avoid colliding with stationary obstacles. PLoS One 5(11):e13912. <https:// dx.doi.org/10.1371/journal.pone.0013912><PMid:21085481>

Owen R.D. 1987. Phylogenetic analyses of the bat subfamily Stenodermatinae (Mammalia: Chiroptera). Spec. Publ. Mus. Tex. Tech. Univ. 26:1-65.
Oyster C.W., Takahashi E.S. \& Hurst D.C. 1981. Density, soma size, and regional distribution of rabbit retinal ganglion cells. J. Neurosci. 1(12):13311346. <https://dx.doi.org/10.1523/JNEUROSCI.01-12-01331.1981> <PMid:7320749>

Park E.B., Gu Y.N. \& Jeon C.J. 2017. Immunocytochemical localization of cholinergic amacrine cells in the bat retina. Acta histochem. 119(4):428437. <https://dx.doi.org/10.1016/j.acthis.2017.04.009><PMid:28483062>

Passos F.C. \& Graciolli G. 2004. Observações da dieta de Artibeus lituratus (Olfers) (Chiroptera, Phyllostomidae) em duas áreas do sul do Brasil. Revta Bras. Zool. 21(3):487-489. <https://dx.doi.org/10.1590/S0101$81752004000300010>$

Passos J.G. \& Passamani M. 2003. Artibeus lituratus (Chiroptera, Phyllostomidae): biologia e dispersão de sementes no Parque do Museu de Biologia Prof. Mello Leitão, Santa Teresa (ES). Natureza on line 1(1):1-6.

Pedler C. \& Tilley R. 1969. The retina of a fruit bat (Pteropus giganteus Brünnich). Vision Res. 9(8):909-922.<https://dx.doi.org/10.1016/00426989(69)90097-2><PMid:5802397>

Pereira A.D., Reis N.R., Orsi M.L. \& Magnoni A.P.V. 2019. Dieta de Artibeus lituratus (Olfers, 1818) (Mammalia, Chiroptera) em um fragmento florestal urbano da cidade de Londrina, Paraná, Brasil. Biotemas 32(2):79-86. <https://dx.doi.org/10.5007/2175-7925.2019v32n2p79>

Pettigrew J.D., Dreher B., Hopkins C.S., MCcall M.J. \& Brown M. 1988. Peak Density and Distribution of Ganglion Cells in the Retinae of Microchiropteran Bats: Implications for Visual Acuity (Part 1 of 2). Brain Behav. Evol. 32(1):48-56. <https://dx.doi.org/10.1159/000116531><PMid:3191381>

Provis J.M. 1979. The distribution and size of ganglion cells in the retina of the pigmented rabbit: a quantitative analysis. J. Comp. Neurol. 185(1):121137. <https://dx.doi.org/10.1002/cne.901850108> <PMid:429611>

Qijiu W., Junfeng L. \& Yumei X. 1981. The numbers and diameter spectra of fibers of the optic nerve of bats (Pipistrellus abramus). Acta Zool. Sin. 27(4):337-341.

Rapaport D.H. \& Stone J. 1984. The area centralis of the retina in the cat and other mammals: focal point for function and development of the visual system. Neuroscience 11(2):289-301. <https://dx.doi.org/10.1016/03064522(84)90024-1><PMid:6425714>

Redondo R.A., Brina L.P., Silva R.F., Ditchfield A.D. \& Santos F.R. 2008. Molecular systematics of the genus Artibeus (Chiroptera: Phyllostomidae). Mol. Phylogenet. Evol. 49(1):44-58. <https://dx.doi.org/10.1016/j. ympev.2008.07.001><PMid:18662791>

Reis N.R., Peracchi A.L., Pedro W.A. \& Lima I.P. 2007. Morcegos do Brasil. Universidade Estadual de Londrina, Londrina. 253p.

Reis N.R., Peracchi A.L., Pedro W.A. \& Lima I.P. 2011. Mamíferos do Brasil. $2^{\text {a }}$ ed. Universidade Estadual de Londrina, Londrina. 439p.

Rodrigues F.V. 2010. Fisiologia sensorial. Rev. Biol. 5:24-35. <https://dx.doi. org/10.7594/revbio.05.06>

Rodríguez-Herrera B., Rodríguez P., Watson W., McCracken G.F., Medellín R.A. \& Galván I. 2019. Sexual dichromatism and condition-dependence in the skin of a bat. J. Mammal. 100(2):299-307. <https://dx.doi.org/10.1093/ jmammal/gyz035>

Rother G. \& Schmidt U. 1982. The influence of visual information on echolocation in Phyllostomus discolor (Chiroptera). Mamm. Biol. 47(6):324-334.

Ruczynski I., Szarlik A. \& Siemers B.M. 2011. Conspicuous visual cues can help bats to find tree cavities. Acta Chiropt. 13(2):385-389. <https:// dx.doi.org/10.3161/150811011X624857>

Rydell J. \& Eklöf J. 2003. Vision complements echolocation in an aerial-hawking bat. Naturwissenschaften 90(10):481-483.<https://dx.doi.org/10.1007/ s00114-003-0464-x><PMid:14564410>

Sadier A., Davies K.T.J., Yohe L.R., Yun K., Donat P., Hedrick B.P., Dumont E.R., Dávalos L.M., Rossiter S.J. \& Sears K.E. 2018. Multifactorial processes 
underlie parallel opsin loss in neotropical bats. eLife 7:e37412. <https:// dx.doi.org/10.7554/eLife.37412><PMid:30560780>

Schlamp C.L., Montgomery A.D., Mac Nair C.E., Schuart C., Willmer D.J. \& Nickells R.W. 2013. Evaluation of the percentage of ganglion cells in the ganglion cell layer of the rodent retina. Mol. Vis. 19:1387-1396. <PMid:23825918>

Shinozaki A., Hosaka Y., Imagawa T. \& Uehara M. 2010. Topography of ganglion cells and photoreceptors in the sheep retina. J. Comp. Neurol. 518(12):23052315. <https://dx.doi.org/10.1002/cne.22333><PMid:20437529>

Simmons N.B. 2005. Order Chiroptera, p.312-529. In: Wilson D.E. \& Reeder D.M. (Eds), Mammal Species of the World: a taxonomic and geographic reference. 3rd ed. The Johns Hopkins University Press, Baltimore, MD.

Simões B.F., Foley N.M., Hughes G.M., Zhao H., Zhang S., Rossiter S.J. \& Teeling E.C. 2018. As blind as a bat? Opsin phylogenetics illuminates the evolution of color vision in bats. Mol. Biol. Evol. 36(1):54-68. <https:// dx.doi.org/10.1093/molbev/msy192><PMid:30476197>

Solari S., Hoofer S.R., Larsen P.A., Brown A.D., Bull R.J., Guerrero J.A., Ortega J., Carrera J.P., Bradley R.D. \& Baker R.J. 2009. Operational criteria for genetically defined species: analysis of the diversification of the small fruit-eating bats, Dermanura (Phyllostomidae: Stenodermatinae). Acta Chiropt. 11(2):279-288. <https://dx.doi.org/10.3161/150811009X485521>

Spoelstra K., Van Grunsven R.H., Ramakers J.J., Ferguson K.B., Raap T., Donners M., Veenendaal E.M. \& Visser M.E. 2017. Response of bats to light with different spectra: light-shy and agile bat presence is affected by white and green, but not red light. Proc. Royal Soc. B 284(1855):20170075.<https:// dx.doi.org/10.1098/rspb.2017.0075><PMid:28566484>

Stone J. 1981. The Wholemount Handbook: A Guide to the Preparation and Analysis of Retinal Wholemounts. Maitland publications, Sydney. 128p.

Suthers R.A. \& Wallis N.E. 1970. Optics of the eyes of echolocating bats. Vision Res. 10(11):1165-1173. <https://dx.doi.org/10.1016/00426989(70)90034-9><PMid:5508963>

Suthers R.A. 1966. Optomotor responses by echolocating bats. Science 152(3725):1102-1104.<https://dx.doi.org/10.1126/science.152.3725.1102>

Suthers R.A., Chase J. \& Bradford B. 1969. Visual form discrimination by echolocating bats. Biol. Bull. 137(3):535-546. <https://dx.doi. org/10.2307/1540174><PMid:5407182>

Teeling E.C. 2009. Hear, hear: the convergent evolution of echolocation in bats? Trends Ecol. Evol. 24(7):351-354. <https://dx.doi.org/10.1016/j. tree.2009.02.012><PMid:19482373>

Teeling E.C., Scally M., Kao D.J., Romagnoli M.L., Springer M.S. \& Stanhope M.J. 2000. Molecular evidence regarding the origin of echolocation and flight in bats. Nature 403(6766):188-192.<https://dx.doi.org/10.1038/35003188> <PMid:10646602>
Thiagavel J., Cechetto C., Santana S.E., Jakobsen L., Warrant E.J. \& Ratcliffe J.M. 2018. Auditory opportunity and visual constraint enabled the evolution of echolocation in bats. Nat. Commun. 9:1-10.<https://dx.doi.org/10.1038/ s41467-017-02532-x>

Tolosa E.M.C., Rodrigues C.J., Behmer A.O. \& Freitas Neto A.G. 2003. Manual de Técnicas para Histologia Normal e Patológica. $2^{\text {a }}$ ed. Editora Manole, Barueri, SP. 331p.

Ullmann J.F., Moore B.A., Temple S.E., Fernández-Juricic E. \& Collin S.P. 2011. The retinal wholemount technique: a window to understanding the brain and behaviour. Brain Behav. Evol. 79(1):26-44.<https://dx.doi. org/10.1159/000332802><PMid:22142853>

Veilleux C.C. \& Kirk E.C. 2014. Visual acuity in mammals: effects of eye size and ecology. Brain. Behav. Evol. 83(1):43-53. <https://dx.doi. org/10.1159/000357830><PMid:24603494>

Vizotto I.D. \& Taddei V.A. 1973. Chave para determinação de quirópteros brasileiros. Revta Facul. Filos. Ciênc. Let. S. José Rio Preto 1:1-72.

Wang D., Oakley T., Mower J., Shimmin L.C., Yim S., Honeycutt R.L., Tsao H. \& Li W.-H. 2004. Molecular evolution of bat color vision genes. Mol. Biol. Evol. 21(2):295-302. <https://dx.doi.org/10.1093/molbev/msh015> $<$ PMid:14660703>

Warnecke M., Macías S., Falk B. \& Moss C. F. 2018. Echo interval and not echo intensity drives bat flight behavior in structured corridors. J. Exp. Biol. 221(Pt24)jeb191155. <https://dx.doi.org/10.1242/jeb.191155> <PMid:30355612>

Wassle H. \& Boycott B.B. 1991. Functional architecture of the mammalian retina. Physiol. Rev. 71(2):447-480. <https://dx.doi.org/10.1152/ physrev.1991.71.2.447><PMid:2006220>

Williams D.R. \& Coletta N.J. 1987. Cone spacing and the visual resolution limit. J. Opt. Soc. Am. A 4(8):1514-1523. <https://dx.doi.org/10.1364/ JOSAA.4.001514>

Williams T.C \& Williams J.M. 1970. Radio tracking of homing and feeding flights of a neotropical bat, Phyllostomus hastatus. Anim. Behav. 18(Part.2):302309. <https://dx.doi.org/10.1016/S0003-3472(70)80042-2>

Winter Y., López J. \& Von Helversen 0. 2003. Ultraviolet vision in a bat. Nature 425(6958):612-614. <https://dx.doi.org/10.1038/nature01971> $<$ PMid:14534585>

Zhao H., Rossiter S.J., Teeling E.C., Li C., Cotton J.A. \& Zhang S. 2009. The evolution of color vision in nocturnal mammals. Proc. Natl. Acad. Sci. U.S.A. 106(22):8980-8985. <https://dx.doi.org/10.1073/pnas.0813201106> <PMid:19470491> 